\title{
Monitoring of Airborne Mercury: Comparison of Different Techniques in the Monte Amiata District, Southern Tuscany, Italy
}

\author{
Valentina Rimondi ${ }^{1,2}, *(\mathbb{D})$, Renato Benesperi $\left.{ }^{3}{ }^{(}\right)$, Marc W. Beutel ${ }^{4}\left(\mathbb{D}\right.$, Laura Chiarantini ${ }^{1,5}{ }^{(0)}$, \\ Pilario Costagliola ${ }^{1,2}\left(\mathbb{D}\right.$, Pierfranco Lattanzi ${ }^{2}\left(\mathbb{D}\right.$, Daniela Medas ${ }^{6}\left(\mathbb{C}\right.$ and Guia Morelli ${ }^{2}(\mathbb{C}$ \\ 1 Dipartimento di Scienze della Terra, Università di Firenze, Via G. La Pira 4, 50121 Firenze, Italy; \\ laura.chiarantini@unifi.it (L.C.); pilario.costagliola@unifi.it (P.C.) \\ 2 CNR-IGG, Via G. La Pira 4, 50121 Firenze, Italy; pierfrancolattanzi@gmail.com (P.L.); \\ guia.morelli@igg.cnr.it (G.M.) \\ 3 Dipartimento di Biologia, Università di Firenze, Via G. La Pira 4, 50121 Firenze, Italy; \\ renato.benesperi@unifi.it \\ 4 University of California, Merced, 5200 Lake Road, Merced, CA 95343, USA; mbeutel@ucmerced.edu \\ 5 Centro di Servizi di Microscopia Elettronica e Microanalisi (M.E.M.A), Università di Firenze, Via G. Capponi \\ 3r, 50121 Firenze, Italy \\ 6 Dipartimento di Scienze Chimiche e Geologiche, Università di Cagliari, S.S. 554 bivio per Sestu, \\ 09042 Monserrato (CA), Italy; dmedas@unica.it \\ * Correspondence: valentina.rimondi@unifi.it; Tel.: +39-055-2757506
}

Received: 4 March 2020; Accepted: 27 March 2020; Published: 31 March 2020

\begin{abstract}
In the present study, mercury $(\mathrm{Hg})$ concentrations were investigated in lichens (Flavoparmelia caperata (L.) Hale, Parmelia saxatilis (L.) Ach., and Xanthoria parietina (L.) Th.Fr.) collected in the surrounding of the dismissed Abbadia San Salvatore $\mathrm{Hg}$ mine (Monte Amiata district, Italy). Results were integrated with $\mathrm{Hg}$ concentrations in tree barks and literature data of gaseous $\mathrm{Hg}$ levels determined by passive air samplers (PASs) in the same area. The ultimate goal was to compare results obtained by the three monitoring techniques to evaluate potential mismatches. Lichens displayed 180-3600 ng/g Hg, and $\mathrm{Hg}$ concentrations decreased exponentially with distance from the mine. Mercury concentration was lower than in Pinus nigra barks at the same site. There was a moderate correlation between $\mathrm{Hg}$ in lichen and $\mathrm{Hg}$ in bark, suggesting similar mechanisms of $\mathrm{Hg}$ uptake and residence times. However, correlation with published gaseous $\mathrm{Hg}$ concentrations (PASs) was moderate at best (Kendall Tau $=0.4-0.5, p>0.05$ ). The differences occurred because a) PASs collected gaseous $\mathrm{Hg}$, whereas lichens and barks also picked up particulate $\mathrm{Hg}$, and b) lichens and bark had a dynamic exchange with the atmosphere. Lichen, bark, and PAS outline different and complementary aspects of airborne $\mathrm{Hg}$ content and efficient monitoring programs in contaminated areas would benefit from the integration of data from different techniques.
\end{abstract}

Keywords: biomonitoring; airborne pollutants; particulate $\mathrm{Hg}$; lichens; tree barks; passive air samplers; mining area

\section{Introduction}

Mercury $(\mathrm{Hg})$ is a widespread contaminant of much concern due to its high toxicity, persistence, and accumulating behavior in the environment [1]. In the reduced form $\left(\mathrm{Hg}^{0}\right), \mathrm{Hg}$ displays long residence times in the atmosphere and a consequent ability to be transported over long distances, making it a global scale pollutant [2]. Now more than ever, the coming into force of the Minamata convention requires the proper monitoring of airborne $\mathrm{Hg}$ contents in order to reduce $\mathrm{Hg}$ anthropogenic 
emissions. An effective estimation of environmental and human health risks to Hg exposure depends on the development of reliable, low cost, easy-to-use monitoring networks [3].

Traditionally, the monitoring of atmospheric $\mathrm{Hg}$ has been accomplished by instrumental techniques, like Light Detection and Ranging (LIDAR; [4]), and compact analyzers, such as Tekran®and Lumex@instruments [5]. These methods are excellent to characterize point sources [6]. However, they lack spatial resolution and provide only short-term information on $\mathrm{Hg}$ contamination [6,7].

Biomonitoring is the assessment of gradient of pollutants in naturally occurring living biological material [8]. Among wildlife, mammals, birds, fish, and most recently snakes have been employed as biomarkers for $\mathrm{Hg}$ [9]. In plants, $\mathrm{Hg}$ especially accumulates in lichens, algae and mosses, and in higher plants. The employment of $\mathrm{Hg}$ concentrations in lichens and mosses in situ or after transplantation is a long-established practice for Hg monitoring [10-15]. Recently, the use of higher plant tissues (e.g., tree rings, bark, leaves) has also increased $[13,16,17]$. In addition to the determination of total $\mathrm{Hg}$ in plant tissues, some studies also investigate the adverse effects (such as alteration in transpiration and photosynthesis, imbalance in carbohydrate metabolism and production of secondary stresses) on the growth and metabolism of plants [18].

A recently developed technique for $\mathrm{Hg}$ monitoring is represented by manufactured passive air samplers (PASs), where a bituminous coal-derived, sulfur-impregnated, activated carbon is employed as sorbent for $\mathrm{Hg}$ species [19]. Passive sampling, either by employing living organisms or manmade products, is a more sustainable and ecologically relevant approach to monitor $\mathrm{Hg}$ for longer periods of time [20-22] and allows a better detection of nonpoint sources of $\mathrm{Hg}$ and better spatial resolution [6,7].

The different monitoring techniques, relying on different processes, do not necessarily give compatible results. Hence, several attempts have been made to evaluate the reliability and comparability of technical and biological methods to monitor $\mathrm{Hg}$ in the atmosphere [8], as well as the interchangeability of substrata. For example, epiphytic lichens in mining areas were found to accumulate more $\mathrm{Hg}$ than mosses due to differences in morphology and ecophysiology $[23,24]$. This has led some authors to conclude that the best monitoring programs are achieved using more than one substratum [25]. To date, studies comparing $\mathrm{Hg}$ contents in tree barks and epiphytic lichens collected at the same sites are not abundant [26-29] and have been mostly conducted in areas with low concentrations of $\mathrm{Hg}$ in air. Additionally, no studies have compared lichens and tree barks with the new recently developed PAS system. To fill this gap, epiphytic lichens and tree barks (Pinus nigra J.F. Arnold) were investigated for $\mathrm{Hg}$ concentrations in the Monte Amiata area (Tuscany, Italy), a regional (possibly global) scale hotspot for $\mathrm{Hg}$ because of the presence of a large abandoned mining and smelting district. These data were compared with the gaseous $\mathrm{Hg}$ concentrations obtained by PASs on the same area. The comparison was based on a limited dataset and should be regarded as preliminary. However, it sets the ground for an optimal, and possibly complementary, use of the different techniques in monitoring programs.

\section{Materials and Methods}

Monte Amiata $\left(42^{\circ} 53^{\prime} 00^{\prime \prime} \mathrm{N} 11^{\circ} 37^{\prime} 00^{\prime \prime} \mathrm{E}\right.$ ) is an extinct Quaternary (ca. $300 \mathrm{Ka}$ ) volcano reaching an elevation of $1738 \mathrm{~m}$ a.s.l. The surrounding area hosts the third largest $\mathrm{Hg}$ mining and production district worldwide ( $>100,000$ tons metal produced), and a present day geothermal field [30]. Mercury mining and smelting operated in the area from 1848 to 1982, although the main production occurred from 1900 to 1970 [31]. The largest mine and smelting plants were near the town of Abbadia San Salvatore (ASSM), located on the eastern slope of the volcano. The environmental legacy of this extensive $\mathrm{Hg}$ mining and metallurgy has been the subject of many studies (see [30] for a partial reference list).

Lichen sampling was performed concurrently with tree bark sampling at 10 sites (Figure 1) in July 2016, making reference to grids established for deployment of PASs [6]: a closer-spaced grid near ASSM (Abbadia grid; sites identified by lowercase a and a progressive number, e.g., a1), and a larger, wider-spaced grid (Amiata grid; sites identified by capital A and a number, e.g., A1), covering an area of $41.6 \mathrm{~km}^{2}$. Having previously decided to sample Pinus nigra trees (to be consistent with the previous study of [16]), the site choice was conditioned by the presence of this species, making efforts to select 
trees as close as possible to a PAS deployment site. We obtained samples of Flavoparmelia caperata (L.) Hale, Parmelia saxatilis (L.) Ach., and Xanthoria parietina (L.) Th.Fr., which were taken whenever possible from the same tree sampled for barks by previous research [32], or at least from a nearby location, at about the same height (approximately $100 \mathrm{~cm}$ to $150 \mathrm{~cm}$ ). It was only possible to collect more than one lichen species at some sites. We estimated that at each site, the lichen samples, the tree sampled for bark, and the next PAS were all within a maximum $20 \mathrm{~m}$ distance (usually less). Collected lichen samples were identified in the field and subsequently verified in the laboratory using a dissecting microscope. The nomenclature of lichens followed [33]. For $\mathrm{Hg}$ concentrations, we decided to use the whole lichen thallus of each sample in order to compare the long-term accumulation performance of the two substrates (lichens and barks).

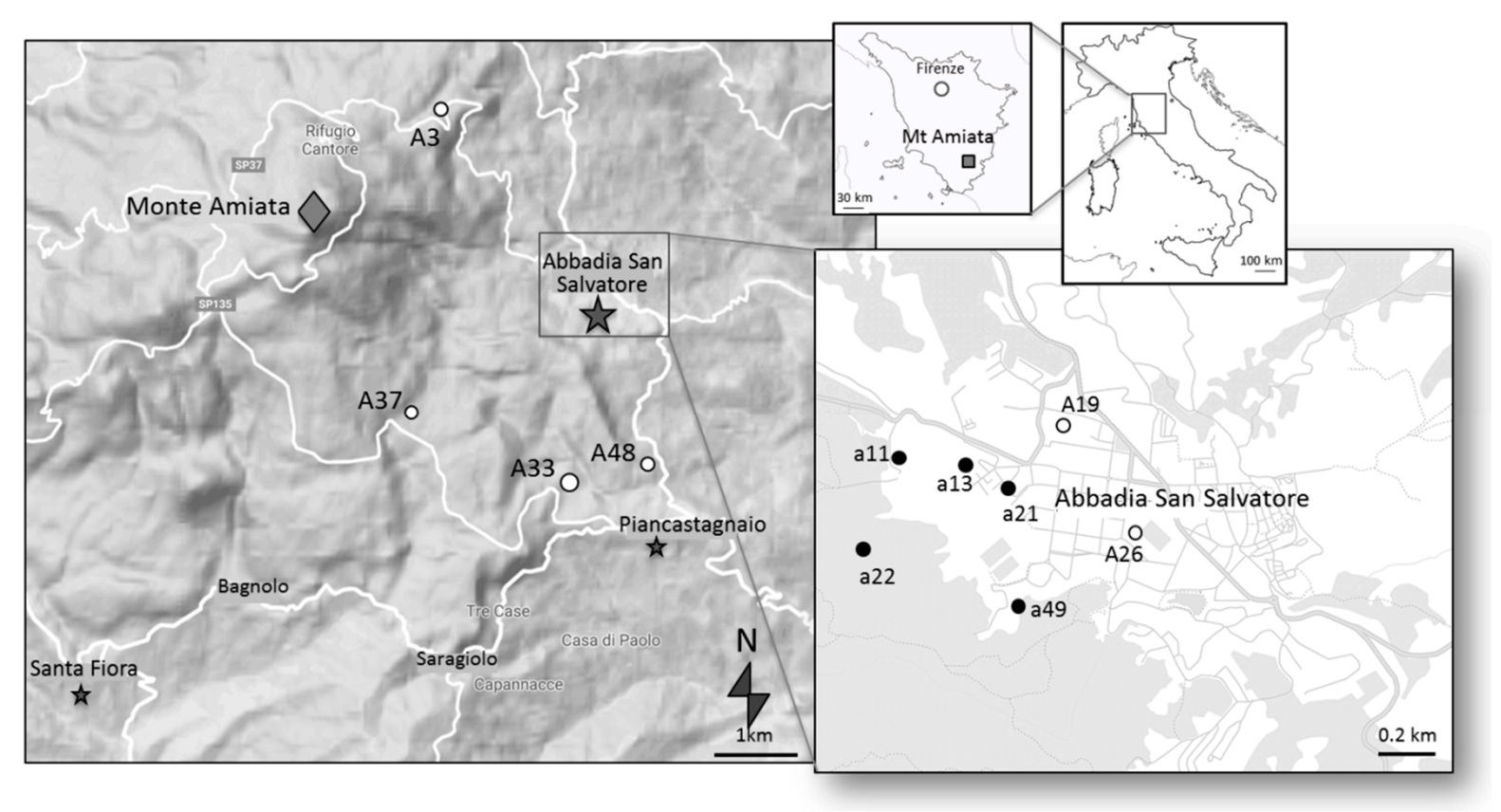

Figure 1. (a) Location of sampling sites in the Monte Amiata area; (b) zoom of sampling sites in the Abbadia San Salvatore town.

Lichen thalli were airdried and carefully cleaned under a dissecting microscope. Then, the lichen material was manually shredded into small pieces and homogenized using a ceramic mortar to obtain three replicates of about $40 \mathrm{mg}$ for each collected species in each site. Lichens were analyzed for total $\mathrm{Hg}$ in triplicate on a Milestone DMA-80 (USEPA method 7473). Results were then expressed as the mean \pm standard deviation. The local gaseous elemental $\mathrm{Hg}$ concentrations (GEM) in the air were taken from [6]. A description of the analytical and computation methods and a description of PAS have been provided by the authors of [6] and [19], respectively. As reported by the authors of [6], deployment times were different for the Amiata and the Abbadia grids. We did not know the specific value of GEM at the moment of bark and lichen sampling. However, the range of values in the time interval including our sampling was fairly narrow. Therefore, they can be assumed to be representative of conditions at sampling time, at least as an order of magnitude (see further discussion).

Because of the small number of samples, linear correlation between variables was explored by the use of the nonparametric Kendall's Tau test.

\section{Results}

Table 1 summarizes, for each site, the $\mathrm{Hg}$ contents (dry weight) in soil, lichens, and Pinus nigra barks, and the range of elemental $\mathrm{Hg}$ concentrations in air estimated from PAS data. For the reasons explained by the authors of [32], for barks, the $\mathrm{Hg}$ concentration was the mean of the four samples 
taken at $150 \mathrm{~cm}$ above ground. Mercury concentrations in lichens (180-3,600 ng/g) were, in general, of the same order of magnitude for the three recognized species (Flavoparmelia caperata (L.) Hale, Parmelia saxatilis (L.) Ach., and Xanthoria parietina (L.) Th.Fr.). For the three sites (a13, a21, and a49), where more than one lichen species was collected, we did not observe a consistent order of enrichment by species. For example, at each of the three sites, a different species exhibited the highest $\mathrm{Hg}$ content (X. parietina, $P$. saxatilis, and F. caperata, respectively). Mercury contents of both X. parietina and F. caperata showed a good (Tau $=0.8)$, statistically significant $(p=0.05)$ correlation with those of the corresponding soil. For $P$. saxatilis, which had only four sample pairs, we did not perform the calculation.

Table 1. Data of $\mathrm{Hg}$ contents in lichens (this study) in tree barks, soils, and $\mathrm{Hg}^{\circ}$ in air (literature data).

\begin{tabular}{|c|c|c|c|c|c|c|}
\hline \multirow{2}{*}{ Site } & \multicolumn{3}{|c|}{ Hg in lichens (ng/g) } & \multirow{2}{*}{$\begin{array}{c}\mathrm{Hg} \text { in bark } \\
(\mathrm{ng} / \mathrm{g})\end{array}$} & \multirow{2}{*}{$\begin{array}{c}\mathrm{Hg} \text { in soil }{ }^{1} \\
(\mathrm{mg} / \mathrm{kg})\end{array}$} & \multirow{2}{*}{$\begin{array}{c}\mathrm{Hg} \text { in air }\left(\mathrm{ng} / \mathrm{m}^{3}\right)^{2} \\
\text { Range }\end{array}$} \\
\hline & $\begin{array}{l}\text { Parmelia } \\
\text { saxatilis }\end{array}$ & $\begin{array}{c}\text { Xanthoria } \\
\text { parietina }\end{array}$ & $\begin{array}{l}\text { Flavoparmelia } \\
\text { caperata }\end{array}$ & & & \\
\hline A3 & $480 \pm 110$ & - & - & $1700 \pm 400$ & $3.7 \pm 0.1$ & $1.68-1.84$ \\
\hline A19 & - & $1200 \pm 280$ & - & $\begin{array}{c}15,700 \pm \\
4200\end{array}$ & $66 \pm 0.4$ & $3.82-4.24$ \\
\hline A33 & - & $920 \pm 300$ & - & $850 \pm 280$ & $4.1 \pm 0.4$ & $2.67-3.26$ \\
\hline A37 & $180 \pm 50$ & - & - & $920 \pm 330$ & $1.1 \pm 0.1$ & $1.86-2.07$ \\
\hline A48 & - & - & $290 \pm 50$ & $230 \pm 110$ & $1.5 \pm 0.1$ & $2.03-3.03$ \\
\hline a11 & - & $2000 \pm 450$ & - & $7500 \pm 980$ & $480 \pm 1$ & $9.86-15.7$ \\
\hline a13 & $1800 \pm 150$ & $3600 \pm 820$ & $3200 \pm 430$ & $\begin{array}{c}19,500 \pm \\
2700\end{array}$ & $186 \pm 1$ & $16-17.9$ \\
\hline $\mathrm{a} 21$ & $1600 \pm 300$ & - & $1400 \pm 230$ & $7600 \pm 500$ & $97 \pm 1$ & $11.6-17.8$ \\
\hline a22 & - & - & $1500 \pm 130$ & $7300 \pm 1300$ & $66 \pm 3$ & $7.48-14.8$ \\
\hline $\mathrm{a} 49$ & - & $1500 \pm 120$ & $2400 \pm 330$ & $10,700 \pm 700$ & $163 \pm 1$ & $24.7-116$ \\
\hline
\end{tabular}

${ }^{1}$ from [32]; ${ }^{2}$ data for June 30 through July 6, 2016 (a11-a49) and from July 4 through October 10, 2016 (A3-A48) from [6].

Lichen concentrations were consistently lower (up to an order of magnitude) than bark concentrations $(850-19,500 \mathrm{ng} / \mathrm{g}$ ) at the same location, with the exception of site A48, where concentrations were very similar ( 230 and $290 \mathrm{ng} / \mathrm{g}$ for barks and lichens, respectively). In a bivariate plot (Figure 2), $\mathrm{Hg}$ concentrations in lichens and barks appear positively correlated. The correlation was strong (Tau $=0.8$ ) and statistically significant $(p=0.05)$ for the species $F$. caperata, while the correlation was weak (Tau $=0.4)$ and not significant $(p=0.3)$ for X. parietina.

For gaseous $\mathrm{Hg}$ concentrations, the highest values were observed at site a49, which was located close to the mine (Figure 1b). Consistently, lower values $\left(<5 \mathrm{ng} / \mathrm{m}^{3}\right)$ were found in the Amiata grid (Figure 1a), located at background sites with respect to the pollution source (Abbadia $\mathrm{Hg}$ mine). However, the correlation between $\mathrm{Hg}$ in bark/ $\mathrm{Hg}$ in lichens and gaseous $\mathrm{Hg}$ was moderate $(\mathrm{Tau}=0.4-0.5$, $p>0.05)$. 


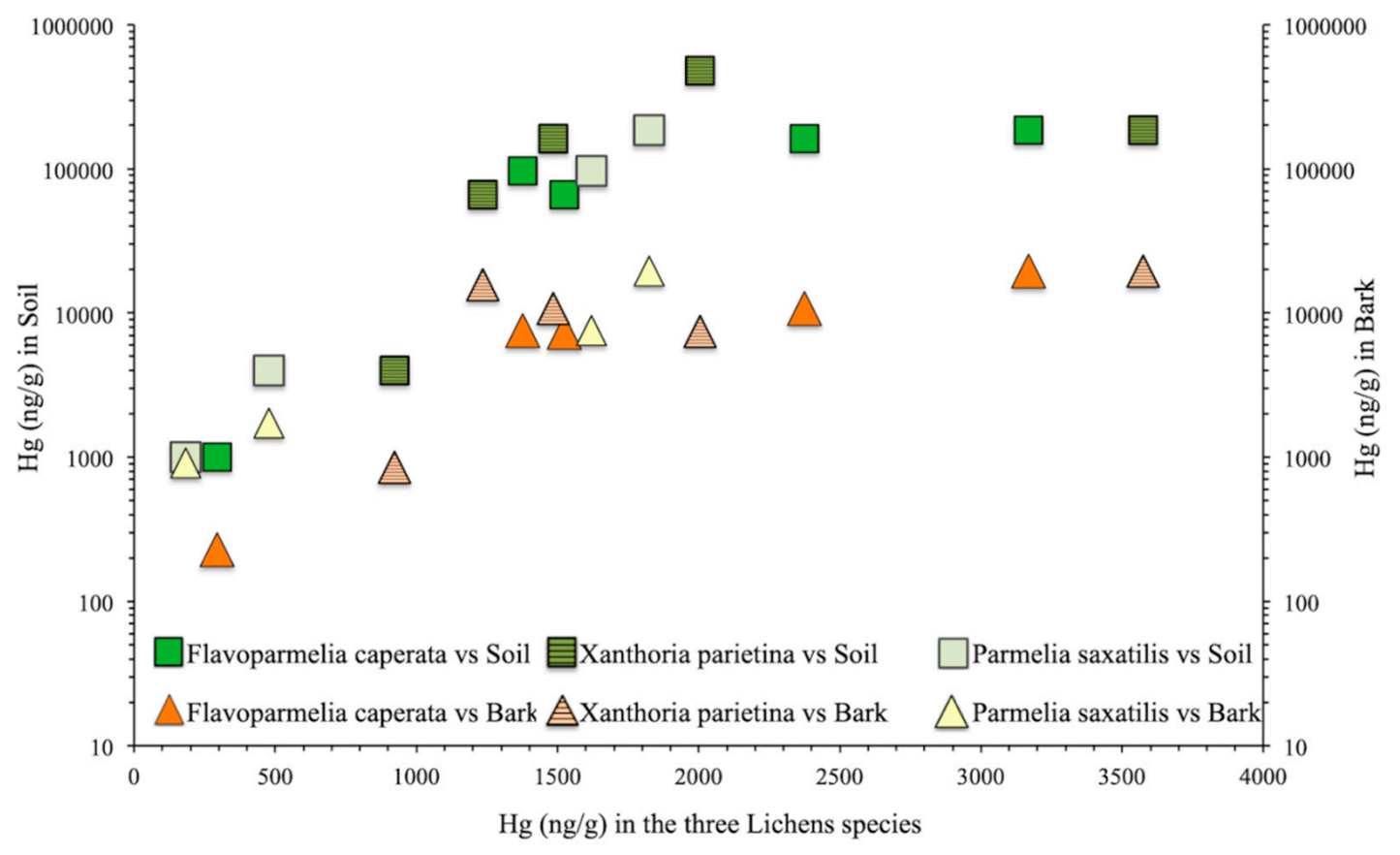

Figure 2. Correlation between $\mathrm{Hg}$ contents in lichens, barks, and soils.

\section{Discussion}

Mercury concentrations in lichens were the same order of magnitude as those previously reported for lichen species in the Monte Amiata area [34-37]. Specifically, for X. parietina, the concentrations reported here $(920-3,600 \mathrm{ng} / \mathrm{g})$ were mostly higher than those $(10-1,960 \mathrm{ng} / \mathrm{g})$ reported by the authors of [37]. Notably, these authors analyzed only the outermost part of the lichens. On the other hand, very high concentrations (up to $40 \mathrm{mg} / \mathrm{kg}$ ) were reported by the authors of [34,35] in samples of Parmelia sulcata directly exposed to ventilations shafts of ASSM. Those authors also showed a decrease of $\mathrm{Hg}$ contents lichen with distance from ASSM similar to our data (compare Figure 3 in [34] with our Figure 3). Compared to other worldwide mining locations, $\mathrm{Hg}$ contents in lichens from Monte Amiata were slightly lower than the values (up to $4,500 \mathrm{ng} / \mathrm{g} \mathrm{Hg}$ ) found in native lichens sampled in the Almadén Hg district in Spain [38], but generally higher than the range of 60-520 ng/g reported for Nova Scotia, where gold mining was active from 1861 to 1942 [7]. 


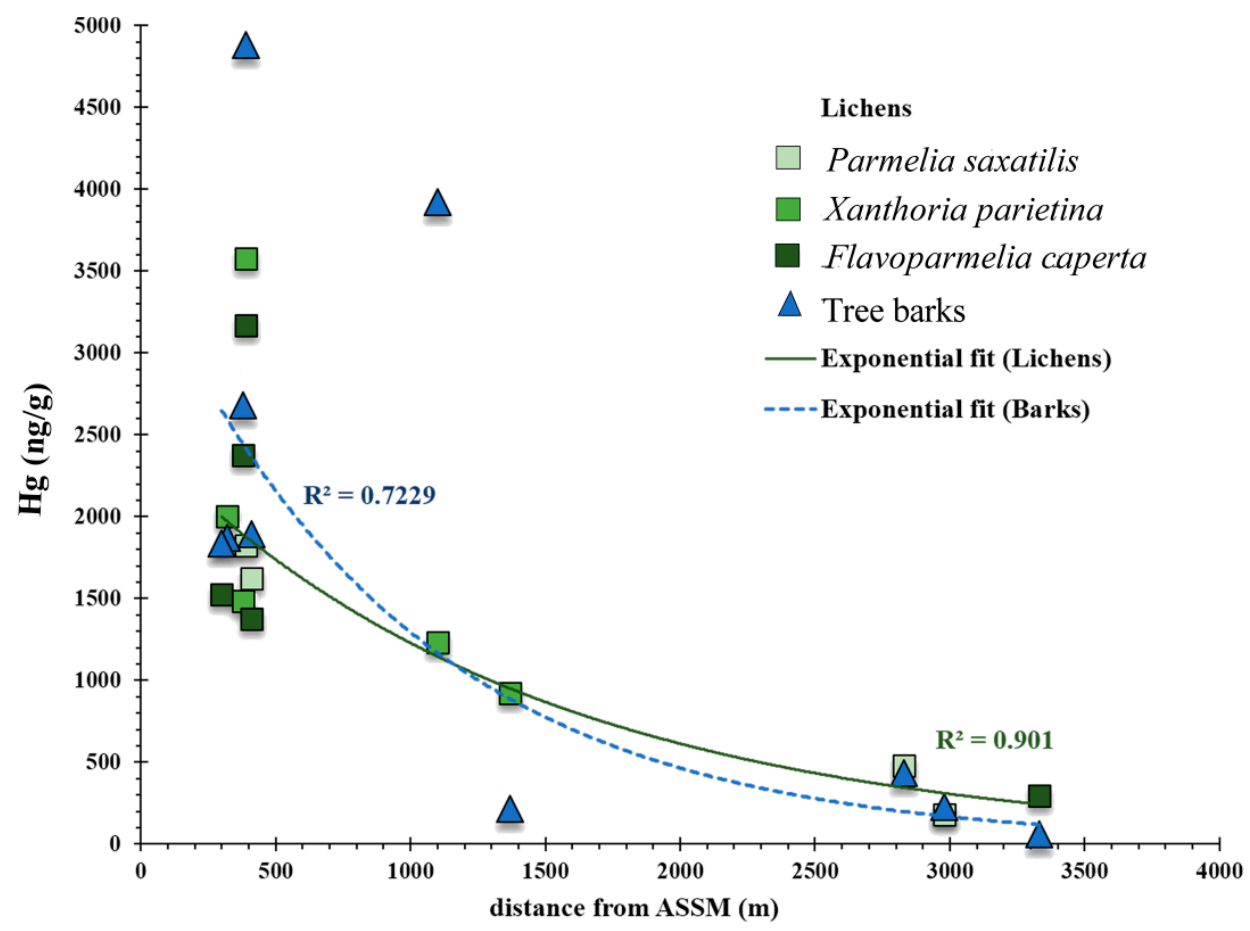

Figure 3. Variations of $\mathrm{Hg}$ contents in barks and lichens as a function of distance from Abbadia San Salvatore (ASSM) (consistent with [6], the origin was taken at their site a32). For a better graphical comparison, the values for barks were divided by four. At sites where more than one lichen species was present, the fit was calculated considering the average of values.

Mercury content in lichen showed a good correlation with local $\mathrm{Hg}$ soil content, which is consistent with previous reports [35]. Working on a slightly larger bark sample set, a statistically significant correlation was established between $\mathrm{Hg}$ contents in barks and soil [32]. The comparison of lichen and bark data showed that the $\mathrm{Hg}$ scavenging efficiency per mass unit was generally higher for barks. By contrast, in other studies (dealing with different lichen and plant species), $\mathrm{Hg}$ contents were found to be higher in lichens than in tree barks [26-29]. At present, the mechanism regulating $\mathrm{Hg}$ uptake by lichens or bark is unknown. However, the fairly good correlation between the contents in the two matrices suggests that uptake mechanisms may be largely similar. Both substrates may take up $\mathrm{Hg}$ as gaseous species (mostly $\mathrm{Hg}^{0}$ ) and as particulate matter. As reviewed by the authors of [39], $\mathrm{Hg}^{0}$ taken up by lichens could be rapidly oxidized to water-soluble $\mathrm{Hg}^{2+}$ by catalase, an enzyme involved in cell protection against oxidative stress, and $\mathrm{Hg}$ contained in adsorbed particulate matter may also be transformed by organic radicals into different compounds. There is no comparable knowledge of transformations occurring in $\mathrm{Hg}$ speciation in bark, but preliminary results have showed a certain degree of $\mathrm{Hg}$ binding with organic functional groups (mainly thiols) [40]. Both lichens and barks show a dynamic exchange with the atmosphere, i.e., they can release part of the $\mathrm{Hg}$ taken up. This release can occur through (a) mechanical removal by wind/rain of previously adsorbed particles (e.g., [41]), (b) dissolution by rain of soluble species, and (c) re-emission of gaseous $\mathrm{Hg}$ [42,43], a phenomenon which is enhanced in summer. In general, however, the released $\mathrm{Hg}$ is only a small fraction of that taken up. For instance, the authors of [32] observed a negligible release of $\mathrm{Hg}$ by Pinus nigra bark upon $24 \mathrm{~h}$ of batch reaction with deionized water. The residence time of the metal in lichen was estimated to be in the order of a few years (references in [39]). For bark, there are no data, but a weak correlation between $\mathrm{Hg}$ bark content and tree age (tens of years) was observed [32], suggesting that the residence time may be significantly shorter than tree age (i.e., possibly similar to lichen).

By contrast, PASs rapidly and irreversibly trap only gaseous $\mathrm{Hg}$ compounds. The upper limit of the uptake capacity of the carbon sorbent is very high, and it was certainly not exceeded during the deployment at ASSM [6]. The differences between PAS-derived gaseous concentrations and lichen/bark 
Hg contents may therefore be ascribed to the following factors: (a) lichens and barks picked up $\mathrm{Hg}$-bearing solid particles. This contribution is presumably more important near contaminated soils (at Monte Amiata, soils contained ore minerals and/or smelting products, for instance, the presence of $\beta-\mathrm{HgS}$ in barks was demonstrated by [40]); (b) lichens and barks dynamically exchanged $\mathrm{Hg}$ with the atmosphere. This exchange makes lichen not very reliable indicators of $\mathrm{Hg}$ concentrations in air [39]; (c) some of the concentrations obtained with PAS referred to time period of one week only, and the specific wind and temperature conditions prevailing during one of the week-long sampling periods (July 2016) may not be reflective of the long-term average conditions [6]; (d) the time period reflected by the different types of samples was not the same. Whereas PAS measurements represented conditions for clearly defined deployment periods (of one week or three months in the current case), the time period represented by the biological samples was less clearly defined. This can cause discrepancies if there are long-term trends in the concentrations; (e) as previously noted, PAS and sampled lichens/barks were always fairly close, but never exactly coincident. However, we believe that this last factor was of negligible impact. Indeed, PAS data [6] suggest that the spatial air concentration variability is rather smooth and gradual rather than noisy and spotty, so we would not expect very large differences in concentrations over a small scale. Considering these factors, differences in the overall trends, depicted by all three indicators, should not be interpreted as inconsistencies. It is possible that they are all reliable witnesses of different aspects of airborne $\mathrm{Hg}$ contamination. PAS give more accurate estimates of short-term local gaseous $\mathrm{Hg}$ concentrations, whereas lichens and barks give a measure of long-term $\mathrm{Hg}$ pollution near ground level, including deposition of airborne particulate.

Gaseous $\mathrm{Hg}$ is the predominant (>99\%) form of $\mathrm{Hg}$ from natural emissions [44]. However, in mine locations like that of Abbadia, particulate $\mathrm{Hg}$ may be significant due the presence of mine waste next to the town center, where particulate $\mathrm{Hg}$ can be rapidly dispersed by local winds to the surroundings. The direct measurement of particulate $\mathrm{Hg}$ is an expensive task, requiring sophisticate instruments such as Tekran. The employment of barks and/or lichens can offer preliminary, spatially extended information on the presence of such species at a low cost. Once the presence of particulate $\mathrm{Hg}$ is indicated, more detailed specific investigations may be set up for this purpose.

\section{Conclusions}

Comparison of $\mathrm{Hg}$ contents in epiphytic lichens and Pinus nigra barks with gaseous $\mathrm{Hg}$ concentrations in air calculated from PAS data at the same locations in the Monte Amiata area led to the following conclusions: barks accumulated higher $\mathrm{Hg}$ per unit mass with respect to lichens of the same area. However, there was an overall good agreement between lichen and bark data, suggesting similar mechanisms of $\mathrm{Hg}$ uptake and residence times a significant fraction of $\mathrm{Hg}$ in bark and lichens was likely present in the particulate form due to soil resuspension. PAS-derived gaseous concentrations showed a moderate match with lichen/bark concentrations. The main factors contributing to differences included a partly different speciation of trapped $\mathrm{Hg}$, the dynamic exchange of $\mathrm{Hg}$ with the atmosphere, and the rapid response of PAS to local variations compared to longer residence times in lichen and bark the overall consistency of $\mathrm{Hg}$ distribution trends depicted by the three methods suggests that they can be usefully integrated in monitoring programs. We suggest that barks or lichens may be successfully applied to provide preliminary indirect information on the presence of particulate $\mathrm{Hg}$ in different case studies (mining and urban areas, for example) before the employment of more sophisticated and expensive techniques which can lead to its quantification.

Author Contributions: Conceptualization, P.C., P.L., V.R., M.W.B.; methodology, P.C., P.L., V.R., M.W.B.; validation, M.W.B.; investigation, P.C., P.L., V.R., M.W.B.; resources, P.C., V.R., M.W.B., P.L.; data curation, M.W.B.; writing—original draft preparation, P.L., P.C., M.W.B., R.B.; visualization: V.R., L.C., G.M., D.M.; writing-review and editing, P.C., P.L., V.R., M.W.B., L.C., R.B., G.M., D.M.; supervision, P.C., P.L., V.R.; project administration, P.C., P.L., V.R.; funding acquisition, P.C., P.L., M.W.B. All authors have read and agreed to the published version of the manuscript.

Funding: This research received no external funding. This study was partly subsidized by University of Florence funding to P.C. 
Acknowledgments: We would like to thank Director Liying Zhao of the U.C. Merced Environmental Laboratory, and research assistant Alejandra Lopez, for assistance with lichen $\mathrm{Hg}$ analytical work. Frank Wania, Carl Mitchell and Fabrizio Monaci kindly offered useful comments on a preliminary draft; they should not be held responsible for any shortcoming of this paper.

Conflicts of Interest: The authors declare no conflict of interest.

\section{References}

1. Obrist, D.; Kirk, J.L.; Zhang, L.; Sunderland, E.M.; Jiskra, M.; Selin, N.E. A review of global environmental mercury processes in response to human and natural perturbations: Changes of emissions, climate, and land use. Ambio 2018, 47, 116-140. [CrossRef]

2. Selin, N.E. Global biogeochemical cycling of mercury: A review. Ann. Rev. Environ. Resour. 2009, 34, 43-63. [CrossRef]

3. Pirrone, N.; Aas, W.; Cinnirella, S.; Ebinghaus, R.; Hedgecock, I.M.; Pacyna, J.; Sprovieri, F.; Sunderland, E.M. Toward the next generation of air quality monitoring: Mercury. Atmos. Environ. 2013, 80, 599-611. [CrossRef]

4. Edner, H.; Ragnarson, P.; Svanberg, S.; Wallinder, E.; Ferrara, R.; Maserti, B.E.; Bargagli, R. Atmospheric mercury mapping in a cinnabar mining area. Sci. Total Environ. 1993, 133, 1-15. [CrossRef]

5. Global Mercury Observation System, Standard Operational Procedure, Methods for the Determination of TGM and GEM. Available online: www.gmos.eu (accessed on 6 November 2019).

6. McLagan, D.S.; Monaci, F.; Huang, H.; Lei, Y.D.; Mitchell, C.P.J.; Wania, F. Characterization and Quantification of Atmospheric Mercury Sources Using Passive Air Samplers. J. Geophys. Res. Atmos. 2019, 124, 2351-2362. [CrossRef]

7. Klapstein, S.J.; Walker, A.K.; Saunders, C.H.; Cameron, R.P.; Murimboh, J.D.; O’Driscoll, N.J. Spatial distribution of mercury and other potentially toxic elements using epiphytic lichens in Nova Scotia. Chemosphere 2020, 241, 125064. [CrossRef]

8. Lodenius, M. Use of plants for biomonitoring of airborne mercury in contaminated areas. Environ. Res. 2013, 125, 113-123. [CrossRef]

9. Haskins, D.L.; Gogal, R.M.; Tuberville, T.D. Snakes as Novel Biomarkers of Mercury Contamination: A Review. Rev. Environ. Contam. Toxicol. 2020, 249, 133-152.

10. Baldi, F. Mercury pollution in the soil and mosses around a geothermal plant. Water Air Soil Pollut. 1998, 38, 111-119. [CrossRef]

11. Bargagli, R.; Barghigiani, C. Lichen biomonitoring of mercury emission and deposition in mining, geothermal and volcanic areas of Italy. Environ. Monit. Assess. 1991, 16, 265-275. [CrossRef]

12. Vannini, A.; Nicolardi, V.; Bargagli, R.; Loppi, S. Estimating atmospheric mercury concentrations with lichens. Environ. Sci. Technol. 2014, 48, 8754-8759. [CrossRef] [PubMed]

13. Fortuna, L.; Candotto Carniel, F.; Capozzi, F.; Tretiach, M. Congruence Evaluation of Mercury Pollution Patterns Around a Waste Incinerator over a 16-Year-Long Period Using Different Biomonitors. Atmosphere 2019, 10, 183. [CrossRef]

14. Loppi, S.; Nelli, L.; Ancora, S.; Bargagli, R. Accumulation of Trace Elements in the Peripheral and Central Parts of a Foliose Lichen Thallus. Bryologist 1997, 100, 251-253. [CrossRef]

15. Godinho, R.M.; Verburg, T.G.; Freitas, M.C.; Wolterbeek, H.T. Accumulation of trace elements in the peripheral and central parts of two species of epiphytic lichens transplanted to a polluted site in Portugal. Environ. Pollut. 2009, 157, 102-109. [CrossRef] [PubMed]

16. Chiarantini, L.; Rimondi, V.; Benvenuti, M.; Beutel, M.W.; Costagliola, P.; Gonnelli, C.; Lattanzi, P.; Paolieri, M. Black pine (Pinus nigra) barks as biomonitors of airborne mercury pollution. Sci. Total Environ. 2016, 569-570, 105-113. [CrossRef] [PubMed]

17. Yang, Y.; Yanai, R.D.; Driscoll, C.T.; Montesdeoca, M.; Smith, K.T. Concentrations and content of mercury in bark, wood, and leaves in hardwoods and conifers in four forested sites in the northeastern USA. PLoS ONE 2018, 13, e0196293. [CrossRef]

18. Pirzadah, T.B.; Malik, B.; Tahir, I.; Irfan, Q.M.; Rehman, R.U. Characterization of mercury-induced stress biomarkers in Fagopyrum tataricum plants. Int. J. Phytoremediat. 2018, 20, 225-236. [CrossRef]

19. McLagan, D.S.; Mitchell, C.P.J.; Huang, H.; Lei, Y.D.; Cole, A.S.; Steffen, A.; Hung, H.; Wania, F. A high-precision passive air sampler for gaseous mercury. Environ. Sci. Technol. Lett. 2016, 3, 24-29. [CrossRef] 
20. Gjengedal, E.; Steinnes, E. The mobility of metals in the soil-plant system in manipulated catchments: Plant species suitable for biomonitoring of Cd, Pb, Zn, and Rb. Ecol. Eng. 1994, 3, 267-278. [CrossRef]

21. Eid, E.; Shaltout, K. Monthly variations of trace elements accumulation and distribution in above- and below-ground biomass of Phragmites australis (Cav.) Trin. ex Steudel in Lake Burullus (Egypt): A biomonitoring application. Ecol. Eng. 2014, 73, 17-25. [CrossRef]

22. Al-Alam, J.; Chbani, A.; Faljoun, Z.; Millet, M. The use of vegetation, bees, and snails as important tools for the biomonitoring of atmospheric pollution-A review. Environ. Sci. Pollut. Res. 2019, 26, 9391-9408. [CrossRef] [PubMed]

23. Loppi, S.; Bonini, I. Lichens and mosses as biomonitors of trace elements in areas with thermal springs and fumarole activity (Mt. Amiata, central Italy). Chemosphere 2000, 41, 1333-1336. [CrossRef]

24. Bargagli, R.; Monaci, F.; Borghini, F.; Bravi, F.; Agnorelli, C. Mosses and lichens as biomonitors of trace metals. A comparison study on Hypnum cupressiforme and Parmelia caperata in a former mining district in Italy. Environ. Pollut. 2002, 116, 279-287. [CrossRef]

25. Szczepaniak, K.; Biziuk, M. Aspects of the biomonitoring studies using mosses and lichens as indicators of metal pollution. Environ. Res. 2003, 93, 221-230. [CrossRef]

26. Solberg, Y. Studies on the chemistry of lichens, XX. The element concentration of the lichen species Alectoria fremontii and its associated bark substrate of Pinus silvestris. Z. Für Nat. C 1979, 34, 1275-1277. [CrossRef]

27. Zhang, L.; Planas, D.; Qian, J. Mercury concentrations in black spruce (Picea mariana Mill. B.S.P.) and lichens in boreal Quebec, Canada. Water Air Soil Pollut. 1995, 81, 153-161. [CrossRef]

28. Trüe, A.; Panichev, N.; Okonkwo, J.; Forbes, P.B.C. Determination of the mercury content of lichens and comparison to atmospheric mercury levels in the South African Highveld region. Clean Air J. 2012, 21, $19-25$.

29. Navrátil, T.; Nováková, T.; Roll, M.; Shanley, J.B.; Kopáček, J.; Rohovec, J.; Kaňa, J.; Cudlín, P. Decreasing litterfall mercury deposition in central European coniferous forests and effects of bark beetle infestation. Sci. Total Environ. 2019, 682, 213-225. [CrossRef]

30. Rimondi, V.; Chiarantini, L.; Lattanzi, P.; Benvenuti, M.; Beutel, M.W.; Colica, A.; Costagliola, P.; Di Benedetto, F.; Gabbani, G.; Gray, J.E.; et al. Metallogeny, exploitation and environmental impact of the Mt. Amiata mercury ore district (Southern Tuscany, Italy). Ital. J. Geosci. 2015, 134, 75-88. [CrossRef]

31. Strappa, O. Storia delle miniere di mercurio del Monte Amiata. L'Industria Mineraria XXVIII 1997, 4, $252-259$. 5, 336-348; 6, 433-439. (in Italian).

32. Rimondi, V.; Costagliola, P.; Benesperi, R.; Benvenuti, M.; Beutel, M.W. Black pine (Pinus nigra) bark samples as biomonitors of airborne $\mathrm{Hg}$ : Assessment of some sampling parameters toward a standardized sampling protocol. Ecol. Ind. 2020, 112, 106110. [CrossRef]

33. Nimis, P.L.; Martellos, S. ITALIC—The Information System on Italian Lichens; Version 5.0. 2017; Department of Biology, University of Trieste: Trieste, Italy, 2017; Available online: http://dryades.units.it/italic (accessed on 6 November 2019).

34. Bargagli, R.; Iosco, F.P.; Barghigiani, C. Assessment of mercury dispersal in an abandoned mining area by soil and lichen analysis. Water Air Soil Pollut. 1987, 36, 219-225. [CrossRef]

35. Bargagli, R.; Barghigiani, C.; Siegel, B.Z.; Siegel, S.M. Accumulation of mercury and other metals by the lichen Parmelia sulcata at an Italian mine site and a volcanic area. Water Air Soil Pollut. 1989, 45, 315-327. [CrossRef]

36. Loppi, S.; Giomarelli, B.; Bargagli, R. Lichens and mosses as biomonitors of trace elements in a geothermal area (Mt. Amiata, central Italy). Cryptogam. Mycol. 1999, 20, 119-126. [CrossRef]

37. Loppi, S.; Paoli, L.; Gaggi, C. Diversity of epiphytic lichens and Hg contents of Xanthoria parietina thalli as monitors of geothermal air pollution in the Mt. Amiata area (central Italy). J. Atm. Chem. 2006, 53, 93-105. [CrossRef]

38. Berdonces, M.A.L.; Higueras, P.L.; Fernández-Pascual, M.; Borreguero, A.M.; Carmona, M. The role of native lichens in the biomonitoring of gaseous mercury at contaminated sites. J. Environ. Manag. 2017, 186, 207-213. [CrossRef]

39. Bargagli, R. Moss and lichen biomonitoring of atmospheric mercury: A review. Sci. Total Environ. 2016, 572, 216-231. [CrossRef]

40. Chiarantini, L.; Rimondi, V.; Bardelli, F.; Benvenuti, M.; Cosio, C.; Costagliola, P.; Di Benedetto, F.; Lattanzi, P.; Sarret, G. Mercury speciation in Pinus nigra barks from Monte Amiata (Italy): An X-ray absorption spectroscopy study. Environ. Pollut. 2017, 227, 83-88. [CrossRef] 
41. Catinon, M.; Ayrault, S.; Boudouma, O.; Asta, J.; Tissut, M.; Ravanel, P. Atmospheric element deposit on tree barks: The opposite effects of rain and transpiration. Ecol. Indic. 2012, 14, 170-177. [CrossRef]

42. Hanson, P.J.; Lindberg, S.E.; Tabberer, T.A.; Owens, J.G.; Kim, K.-H. Foliar exchange of mercury vapor: Evidence for a compensation point. Water Air Soil Pollut. 1995, 80, 373-382. [CrossRef]

43. Hanson, P.J.; Tabberer, T.A.; Lindberg, S.E. Emissions of mercury vapor from tree bark. Atmos. Environ. 1997, 31, 777-780. [CrossRef]

44. Liu, G.; Cai, Y.; O’Driscoll, N. (Eds.) Overview of mercury in the environment. In Environmental Chemistry and Toxicology of Mercury, 1st ed.; John Wiley \& Sons, Inc.: Hoboken, NJ, USA, 2012; pp. 1-12.

(C) 2020 by the authors. Licensee MDPI, Basel, Switzerland. This article is an open access article distributed under the terms and conditions of the Creative Commons Attribution (CC BY) license (http://creativecommons.org/licenses/by/4.0/). 